DOI: 10.31392/NPU-nc.series14.2019.27.05

УДК: 159.954.3-078.17]:001.19

Лі Еньхуй

\title{
Зміст поняття "музично-слухові уявлення" в сучасних наукових дослідженнях
}

\begin{abstract}
У статті розглянута еволюція поняття «музично-слухові уявлення» і розкриті сучасні погляди науковців на цей феномен. Зазначається, що погляди музикантів-педагогів стосовно важливості його формування змінювалися і залежали від будови і механіки музичного інструменту, зокрема фортепіано. Відповідно змінювалися й методичні системи викладання гри на цьому інструменті - від пріоритету виконавської техніки до процесу інтонування і звукоутворення для формування музично-слухових уявлень. Аналіз сучасних методичних праць з питань музичного навчання показав, що формування музично-слухових уявлень стає основою успішної музичної діяльності, яка дозволяє розкрити особистість учнів і суттєво вплинути на їх музичний розвиток і естетичні уподобання. У виконавському процесі основою формування музично-слухових уявлень виступає слухова активність, яка забезпечує слухорухову координацію, надає виконанню оцінку за художніми та технічними параметрами і таким чином здійснює коригування виконавського процесу та його результату. певний запас музично-інтонаційних уявлень, Уміння оперувати ними, опанування елементарних виконавських навичок стають передумовою безпосередньої участі учнів у творчому процесі виконання музичних творів.

Ключові слова: молодші школярі; музично-слухові уявлення; музична інтонація; музична діяльність, виконавські уміння
\end{abstract}

Актуальність дослідження. Сучасний етап розвитку початкової музичної освіти в різних країнах світу, зокрема в Китаї, характеризується зміною іiі концептуальних засад, що передбачає утвердження мистецтва як вагомого чинника естетичного виховання і своєрідного регулятивного впливу на становлення особистості. Саме 3 музичним мистецтвом пов'язуються перспективи гуманізації освіти, реалізації інноваційних принципів у педагогічному процесі, орієнтованих на здатність особистості бачити, відчувати і споглядати. У зв'язку з цим важливим завданням мистецької освіти на початковому етапі навчання стає формування в учнів музично-слухових уявлень, зумовлених внутрішніми особливостями осягнення смислу музичного твору.

Мета статті - проаналізувати еволюцію поняття «музично-слухові уявлення» $\mathrm{i}$ розкрити сучасні погляди науковців на цей феномен у процесі початкового фортепіанного навчання.

Виклад основного матеріалу. Питання щодо важливості формування музично-слухових уявлень довгий час знаходиться у сфері інтересів багатьох педагогів-музикантів. Шлях, який подолало 3 плином часу трактування цього поняття, відображує процес повільного i поступового усвідомлення його величезної ролі у системі загального музичного розвитку і творчого впливу на результат виконавської діяльності музиканта.

Необхідно зазначити, що погляди музикантів-педагогів стосовно важливості формування музично-слухових уявлень виконавців змінювалися і залежали від будови i механіки музичного інструменту. 3 кінця XVIII століття,коли фортепіано витіснило попереднього «короля» інструментів - клавесин, почала розвиватися й методика навчання гри на фортепіано. Спочатку іï суттєвою характеристикою став пріоритет виконавської техніки над смислом музичного твору. Основним завданням педагога вважалася підготовка виконавцявіртуоза, якому було необхідно навчитися виконувати дуже швидко і голосно найскладніші твори 3 максимальними зовнішніми ефектами. Найкращими якостями виконавця вважалися сила звучання, віртуозність, блискучість, насиченість фактури. На той час виконавцю вже не потрібно було оволодівати композиторськими та імпровізаторськими навичками.

Перші методичні поради стосовно гри на клавесині були створені у XVIII столітті композиторами Ж. Рамо «Метода пальцьової механіки» і К. Ф. Е. Бахом «Досвід справжнього мистецтва гри на клавірі». Головним принципом навчання на клавірі вони проголошували мистецтво гри cantabile, тобто спів на музичному інструменті. Його педагоги розуміли як 
втілення у процесі гри пануючих на той час ідеалів вокально-мовленнєвого відтворення. Зокрема К. Ф. Е. Бах у своєму трактаті наводив низку навичок, якими має оволодіти клавірист: поєднувати один звук 3 іншим, не роз'єднуючи їх за допомогою staccato, використовувати правильну аплікатуру і відпрацьовувати визначені композитором прикраси, домагатися виразного виконання музичного твору. При цьому композитор наголошував, що головним завданням виконавця $€$ донесення до слухача тих афектів, які містяться в музичному творі [2].

Широкої популярності в ті часи набули методичні системи композиторів і педагогів Ф. Калькбреннера та М. Клементі, які мали значний вплив на розвиток теорії і практики навчання гри на фортепіано. Однак вже скоро стали проявлятися недоліки, притаманні цим методикам: пріоритет розвитку технічних умінь і навичок, а головне - відсутність роботи над м'язовою свободою рук. Учням пропонувалося проводити за інструментом довгі години, механічно тренуючи свою техніку. При цьому йому, навіть, пропонували читати під час занять книгу.

Вказані недоліки поступово долалися, а у фортепіанному виконавстві стали приділяти більше уваги «співу» на інструменті. У міру того як фортепіано завойовувало нові позиції, почала з'являтися методична література для цього інструмента. В контексті нашого дослідження привертають увагу праці А. Куллака «Естетика фортепіанної гри»,Ф. КларкШтейннгера «Вчення про єдиний художній засіб для гри на фортепіано», I. Гуммеля «Грунтовне теоретичне і практичне керівництво 3 фортепіанної гри» і К. Черні «Повна теоретична і практична фортепіанна школа». Ці педагоги відстоювали думку, що виразність виконання залежить від здатності музиканта перейматися почуттями, закладеними у музичних творах, вкласти їх у своє виконання і донести до серця слухачів. Ці ідеї стали підгрунтям для поглибленої розробки проблематики звукоутворення на фортепіано i, зокрема, формуванню в процесі навчання музично-слухових уявлень.

Науковий аналіз педагогічної спадщину музикантів наступного періоду засвідчує їх постійну увагу до процесу звукоутворення і формування музично-слухових уявлень. За такими принципами працювали I. Гумель, Е.Зауэр, А.Зилотті,Ф. Шопен, Ф. Ліст, Р. Шуман, Г. фон Бюлов, Т. Лешетицький, К.Таузиг, К. Мартінсен. Завдяки їх учням розроблені цими педагогами методики поступово впроваджувалися у практику фортепіанного навчання різних європейських країн [4].

Цікаво, що у науково-методичних матеріалах, які розкривають діяльність таких видатних на той час педагогів-музикантів, звертається постійна увага на проблему звукоутворення під час виконання творів і формування відповідних музично-слухових уявлень. Відтак у музичному навчанні стали надавати провідного значення слуховому контролю, підкреслюючи роль слухового виховання для формування піаністичних умінь і навичок. Гаслом багатьох педагогів став вислів: «У навчанні потрібно йти від слуху до руху, а не навпаки».

Серед їх рекомендацій особливу увагу привертає ідея К. Мартінсена, згідно якої музичне навчання повинно спрямовуватися на слухове виховання, тому в центрі уваги музиканта має бути звукова мета, яку він називав звукотворчою волею [7].

Наведемо також думки Б. Асафьєва, який надавав значної уваги інтонуванню у процесі виконання. Він навіть запровадив поняття «інтонація рук». За переконанням педагога, мистецтво піанізму належить до найвищих інтелектуальних культур інтонаційно-тембрового виконавства і вимагає найтоншої слухової уваги. Відповідно він поділяв музикантіввиконавців на дві категорії: одні слухають і розуміють музику внутрішнім слухом..., інші чують її тільки тоді, коли музичний твір звучить в голосах або на інструменті $[1,92]$.

Відтак у музичній педагогіці закріпилася думка, що можливість сприймання музики i запам'ятовування почутого народжує здатність до утворення музично-слухових уявлень. Поза цих здібностей неможливим було б не тільки створення музики, а й звичайне іiі виконання. Вже читання «з листа» завжди супроводжується слуховими уявленнями. Читаючи 
ноти очима, музикант чує музику, а граючи їі на інструменті - чує іiі раніше, ніж його пальці торкнуться клавіш.

Ступінь конкретності відчуття може бути різою і залежить від здібностей, досвіду, а також знайомством із стилем i мовою музичного твору. Різними можуть бути й характеристики почутого: одні чують тільки мелодію, інші і мелодію і гармонію, треті додають до цих якостей ще й тембр. Деякі виконавці уявляють собі музику в живих, виразних інтонаціях лише під час читання тих творів, які раніше гралися або були почуті. Інші музиканти можуть уявити звучання тексу раніше не знайомого твору. Можливі й уявлення вільно комбінованих стереотипів звучання, накопичених слухом і музичним мисленням 3 видозмінами. Про таку здібність говорять як про творчу уяву або фантазію.

Музиканти, а за ними і деякі психологи визначають здатність уявляти музику як внутрішній слух, протиставляючи його зовнішньому слуху, тобто здатність чути і сприймати музику, яка звучить зовні. При цьому зовнішній слух оцінюється як нижча ступінь розвитку музичного слуху. Вперше таку думку висловили М. Римський-Корсаков і С. Майкапар. Вони вважали, що музичний слух у широкому значенні цього слова виходить не тільки за межі відчуття, а й за межі сприймання. Музичний слух вони розуміли як здатність сприймати $\mathrm{i}$ представляти музичні образи, які нерозривно пов'язані з образами пам'яті й уяви.

Дослідження Б.Теплова, О. Щапова, С. Савшинського також показали, що музичнослухові уявлення відносяться до першочергових виконавських здібностей (адже перш ніж почати виконання твору, музикант повинен внутрішньо його почути, пережити, створити яскраві поетичні образи, які він реалізує через виконавську техніку. Підтвердження цієї думки знаходимо у дослідженні А. Сохора «Музика як вид мистецтва», який підкреслює: «усвідомлене сприйняття музики, іiі розуміння і переживання можливі тільки на основі визначеного кола слухацьких уявлень, асоціацій, навичок, музично-слухового досвіду людини, що вимагає кількісного розширення та якісного збагачення її «тезаурусу» [10, 71-72].

На сьогоднішній день різні аспекти музичного слуху розглядаються в теоретичних $\mathrm{i}$ методичних працях музикантів-педагогів, які визначають необхідність його розвитку в умовах музичного навчання. Аналіз останніх досліджень і публікацій свідчить, що значна частина українських та зарубіжних науковців (Гу Сяохун, В. Макаров, А.Малинковская, Г. Ціпин, Лю Цинган [3, 5, 6, 11, 12]) вважають формування музично-слухових уявлень основою успішної музичної діяльності, яка дозволяє розкрити особистість учнів і суттєво вплинути на їх музичний розвиток і естетичні уподобання. Автори підкреслюють, що головна функція дитячого музичного навчання полягає в його художньо-естетичному змісті, оскільки музика розвиває емоційно-чуттєву сферу, увагу і мислення, формує шляхетні якості.

Формування музично-слухових уявлень - це вміння слухати себе під час виконання. Необхідність чути себе під час виконання визнавалась практично всіма педагогами. Вони зазначали, що слухання музики можливе лише у виконанні, тобто процесі, який обов'язково містить в собі емоційне настроювання. Невміння слухати себе завжди збіднює виконання, робить його недосконалим. При цьому характер музики також змінюється і часто не відповідає задуманому композитором, а учень-виконавець навіть і не помічає цього.

У виконавському процесі основою формування музично-слухових уявлень виступає слухова активність, яка забезпечує слухо-рухову координацію, надає виконанню оцінку за художніми та технічними параметрами і таким чином здійснює коригування виконавського процесу та його результату. Музично-слухова активність проявляється у зосередженості на певних «художньо-смислових орієнтирах», зумовлених логікою сприймання музичного твору. Такі «художньо-смислові орієнтири» включають: інтонаційну та образну виразність, а також драматургічну логічність, що в цілому сприяє досягненню художньо-осмисленого виконавського результату. Їх виокремлення у виконавському процесі сприяє поступовому формуванню музично-слухових уявлень від конкретно-чуттєвих до художньо-асоціативних й концептуально-визначених. Будучи сформованим у свідомості музиканта, вони стають 
«зразком», «ідеальною моделлю» для яскравого і емоційного звукового втілення у музичному виконанні.

Разом 3 тим зосередженість на «художньо-смислових» орієнтирах у процесі засвоєння музичного твору стає основою художньо-аналітичної діяльності, результатом якої виступає аналіз музичного твору як художньо-смислового об'єкту. Виховання вміння слухати себе, формувати свої музично-слухові уявлення постійно відкриває перед учнями нові можливості збагатити, поглибити і покращити своє виконання, надати йому максимум виразності і тим самим надати учню справжнє творче задоволення. Однак практика показує, що далеко не всі учні навіть високого рівня просування вміють слухати себе.

Розмірковуючи над цією проблемою, педагоги дійшли висновку, що головна проблема полягає в наступному: слухання своєї гри вимагає постійного напруження уваги, неперервного «включення» учня під час занять. Така зібраність на початку навчання дається учням іноді дуже важко. Особливо складною вона виявляється для дітей, які швидко втомлюються. Якщо учень продовжує займатися 3 малим ступенем зосередженості, він поступово звикає грати неуважно, не слухаючи себе у виконанні.

Навчившись слухати себе, учень знову набуває свободи і захопленості виконанням вже на іншому, більш високому рівні. Слухати свою гру неважко, якщо слухання відбувається постійно. Тому учня необхідно ще 3 перших кроків навчання навчити слухати себе, а потім слідкувати за розвитком цього уміння на всіх етапах музичної освіти, оскільки ускладнення репертуару веде за собою й ускладнення завдань для слухання.

Шляхи формування умінь слухати себе можуть бути різними, але вони завжди мають бути конкретними, адже загальні розмови щодо необхідності слухати себе не дають позитивних результатів. Вміння слухати себе формується тільки на конкретних вимогах до звучання. Тільки тоді учень буде розуміти, що педагог хоче від нього.

Необхідно також зазначити, що конкретний звуковий образ музичного твору і його частин не з'являється сам по собі. Він виникає у роботі - під час гри і слухового контролю, а також активних пошуків найкращого звукового втілення своїх музичних уявлень. Так поступово у процесі роботи над твором і безпосереднім слуханням своєї гри формується звуковий задум і розвиваються музично-слухові уявлення.

Педагогічний досвід багатьох вчителів свідчить, що недостатня увага до питань формування музично-слухових уявлень у починаючих музикантів згодом переходить у хронічну «глухоту», тобто збіднює виконавські можливості музиканта. Зміст виконавського мистецтва полягає в інтонаційно-переконливому звуковому відтворенні музичного твору. Так само, як людина володіє певною манерою - вимовляти слова, чітко або не розбірливо, швидко або повільно, широко користується інтонаційними підвищеннями і пониженнями голосу або говорить монотонно, - так і в музичному мистецтві прийоми використання виразних засобів характеризують певний тип звукообразного мислення, творчу індивідуальність, стиль даного виконавця.

Уявлення щодо виразного інтонування у починаючих піаністів перш за все пов'язані 3 майстерністю виконання мелодії. В основі мелодійної виразності лежить осягнення образноемоційної побудови музики, яке спочатку виникає як безпосереднє ії переживання, узагальнене відчуття, а потім поглиблюється і конкретизується під час детального вивчення логіки мелодичного розвитку, не відокремленого від логіки музичного процесу в цілому. У результаті такої роботи формуються звукові уявлення, які поступово віддзеркалюються у внутрішньому плані виконавця-піаніста $[11,55]$.

Тут доцільно пригадати висловлювання Г. Нейгауза, який писав: «звук $є$ першим i найважливішим засобом (поруч з ритмом) серед інших засобів, якими повинен оволодіти піаніст, але засіб, а не мета» [7, 73], а С. Фейнберг підкреслював:«Не можна говорити про гарний звук поза конкретно поставленого художнього завдання; стиль композитора в цілому і в кожному окремому епізоді, навіть будь-який голос поліфонії вимагає особливого зафарбування і особливого прийому звуковидобування». 
Разом $з$ тим у педагогічній діяльності ще існує практика рухово-моторного навчання. В його основі лежать елементарні дії на клавіатурі, спрямовані на одноманітне і голосне програвання музичного твору у повільному темпі. Розповсюдженню «антислухових» прийомів і способів гри на фортепіано сприяє також те, що деякі педагоги, намагаючись оберегти своїх вихованців від можливої сценічної невдачі, рекомендують їм довгі, чисто механічні тренування, які підвищують ступень вивчення музичного матеріалу. Відпрацювання учнем відповідним ігрових навичок стає в їх практиці самоціллю, а загальне музично-слухове виховання відсувається на другий план.

Так, педагогічний досвід засвідчує, чим складнішою є ситуація в музичній педагогіці, тим більше уваги потрібно приділяти розвитку музично-слухових уявлень. У цьому зв'язку нагадаємо ще думку Г. Нейгауза, який у роботі «Про мистецтво фортепіанної гри» писав: « Я пропоную у всіх складних випадках перш за все добиватися покращення i розвитку музичних, слухових здібностей» [8].

На сьогоднішній день ще недостатньо розроблена теорія і методика розвитку слуху в учнів-піаністів. Педагоги не завжди вміють ставити і вирішувати спеціальні слухо-виховні завдання, не усвідомлюють практично доцільні шляхи такої роботи, недооцінюють іï важливість. Між тим широка фортепіанно-педагогічна практика потребує ефективної методики розвитку музично-слухових уявлень. Така структурно завершена методика особливого значення набуває в системі масової музичної освіти вже на початковому етапі навчання, оскільки в ній навчаються категорії учнів з різними музичними здібностями.

Висновки. Підсумовуючи погляди видатних музикантів-педагогів на процес формування музично-слухових уявлень визначимо декілька позицій, на які педагогам, працюючим 3 починаючими музикантами, слід звернути увагу. Учню-піаністу, який би хотів оволодіти мистецтвом музичного інтонування, не можна випускати 3 поля зору горизонтальні та вертикальні координати фортепіанної тканини, оскільки повноцінне інтонування передбачає осмислення і реалізацію усіх просторово-часових компонентів музичного процесу.

Для того, аби учень навчився слухати себе, йому необхідно точно знати, що саме потрібно слухати. У зв'язку з цим педагог повинен ставити перед учнем конкретні звукові завдання. Сама постановка точних і цікавих виконавських завдань можлива, якщо сам педагог детально знає і відчуває музичний твір. Як відомо, професійна вимогливість до чужого виконання значно зростає, коли твір добре відомий слухачам. У цьому випадку ясні й внутрішні уявлення музики роблять можливою точну оцінку чужого виконання. Це доводить, що педагог-музикант повинен досконало знати твори, які входять до репертуару учня. Таке знання можливе тільки на основі власного виконавського досвіду.

Друге завдання, що стоїть перед педагогом, полягає в тому, щоб навчити учня чути, як він грає у дійсності. Вирішальною умовою тут стає висока професійна вимогливість педагога, його непримиримість 3 недоліками учня. Йому необхідно навчити учня слідкувати за своєю грою і перевіряти себе слухом.

Отже, певний запас музично-інтонаційних уявлень, уміння оперувати ними, опанування елементарних виконавських навичок стають передумовою безпосередньої участі учнів у творчому процесі виконання музичних творів. Такий процес стає найбільш перспективним для музичного навчання в спеціалізованих музичних закладах,а формування музичнослухових уявлень має стати першочерговим завданням педагога-піаніста - метою, яка визначає стратегію і тактику його роботи.

\section{Література}

1. Асафьев Б.В. (1971). Музыкальная форма как процесс. Л.: Музыка. 376 с.

2. Бах К.Ф.Э. (2005). Опыт истинного искусства игры на клавире (пер. с нем. Е. Юшкевича). СПб.: EARLYMUSIC PUBLISHING HOUSE.

3. Гу Сяохун (2001). О музыкальном воспитании в раннем возрасте. «Вестник Хэйлунцзинского образовательного института». Харбин, № 4. с.9. 
4. Кашкадамова Н.Б. (1998) Мистецтво викладання музики на клавішно-струнних інструментах (клавікорд, клавесин, фортепіано) XIV- XVIII ст. [Текст]: навч. посібник для студ. музичних вузів. Вищий держ. музичний ін-т ім. М.Лисенка. Т. : СМП "Астон", 299 с.

5. Макаров В. (1997) Методика обучения игре на фортепиано. Х : ХГИИ. 120 с.

6. Малинковская А.В. (2005). Класс основного музыкального инструмента: искусство фортепианного интонирования. М. : Гуманитар. изд. центр «ВЛАДОС», 382 с.

7. Мартинсен К. А. (2003) Методика индивидуального преподавания игры на фортепиано. М. : Классика-XXI, $127 \mathrm{c.}$

8. Нейгауз Г. Г. (1988). Об искусстве фортепианной игры / Записки педагога. М. : Музыка, 240 с.

9. Савшинский С. И. (1964). Работа пианиста над музыкальным произведением. Л. : Музыка, $188 \mathrm{c}$.

10. Сохор А. Музыка как вид искусства. СПб. : Лань, 128 с.

11. Ципин Г.М. (2001) Музыкально-исполнительское искусство. СПб. : «Альтейя», 320с.

12. Лю Цинган. (2003) Фортепианное исполнительство и обучение. Пекин : Народная музыка. $125 \mathrm{c}$.

\section{Про автора:}

Лі Еньхуй, аспірант факультету мистецтв, Національний педагогічний університет імені М.П. Драгоманова (01054, Київ, Україна)

\section{Essence of the musical auditory perception in modern scientific research}

Li En Hui

The article discusses the evolution of the concept of "musical auditory perception" and discloses modern views of scientists related to this phenomenon. It is noted that the views of the teaching musicians regarding the importance of the concept formation underwent changes and were determined by the structure and mechanics of the musical instrument, in particular the piano. The methodological systems of teaching how to play the piano changed accordingly: the instrumental technique took the inferior position contrary to the process of intonation and sound formation in terms of the formation of musical auditory perception. The analysis of modern methodological publications related to the musical education shows that the formation of musical auditory perception becomes pivotal for the successful musical activity, helps reveal the personality of students and has a significant effect on their musical development and aesthetic preferences.

During the process of performing, the auditory processing activity serves as a basis for the formation of musical auditory perceptions. This activity maintains auditory-motor coordination, assesses the performance according to the artistic and technical parameters whereby encourages adjustments to the process of performance and its outcomes, forms a certain stock of musical and intonational perceptions. The ability to apply these and mastering elementary performing skills allow students to actively involve in the creative process of performing musical works. In this regard, there are two conditions that need to be addressed in the teaching process: the student has to be set an accurate and interesting task; the student has to be trained to hear what he or she actually performs. Based on the accumulated teaching experience, we come to a conclusion that the more complex the situation with the music pedagogy becomes, the more attention should be paid to the development of musical auditory perceptions. Such a process becomes the most favorable in teaching music at specialized musical institutions, and the formation of musical auditory perception should be the main task of a pianist educator.

Keywords: primary schoolchildren; musical auditory perceptions; musical intonation; musical activity; performing skills.

\section{References}

1. 1. Asafev B.V. (1971). Muzykalnaya forma kak protsess. L.: Muzyka. 376 s. [in Russian]

2. Bakh K.F.E. (2005). Opyt istinnogo iskusstva igry na klavire (per. s nem. Ye. Yushkevicha). SPb.: EARLYMUSIC PUBLISHING HOUSE.

3. Hu Syaokhun (2001). O muzykal'nom vospytanyy v rannem vozraste. «Vestnyk Khéyluntszynskoho obrazovatel'noho ynstytuta». Kharbyn, № 4. s.9. [in Russian]

4. Kashkadamova N.B. (1998). Mystetstvo vykladannya muzyky na klavishno-strunnykh instrumentakh (klavikord, klavesyn, fortepiano) XIV- XVIII st. [Tekst]: navch. posibnyk dlya stud. muzychnykh vuziv. Vyshchyy derzh. muzychnyy in-t im. M. Lysenka. T.: SMP "Aston", 299 s. [in Ukrainian] 
5. Makarov V. (1997). Metodika obucheniya igre na fortepiano. Kharkov : KhGII. 120 s. [in Russian]

6. 6. Malinkovskaya A.V. (2005). Klass osnovnogo muzykalnogo instrumenta: iskusstvo fortepiannogo intonirovaniya. M. : Gumanitar. izd. tsentr «VLADOS», 382 s. [in Russian]

7. Martinsen K. A. (2003). Metodika individual'nogo prepodavaniya igry na fortepíano. M: KlassikaXXI, 127 s. [in Russian]

8. Neygauz G. G. (1988). Ob iskusstve fortepiannoy igry / Zapiski pedagoga. M. : Muzyka, 240 s. [in Russian]

9. Savshinskiy S.I. (1964). Rabota pianista nad muzykal'nym proizvedeniyem. L. : Muzyka, 188 s. [in Russian]

10. Sokhor A. Muzyka kak vid iskusstva. SPb. : Lan', 128 s. [in Russian]

11. Tsipin G.M. (2001). Muzykal'no-ispolnitel'skoye iskusstvo. SPb. : «Al'teyya», 320 s. [in Russian]

12. Lyu Tsingan. (2003). Fortepiannoye ispolnitel'stvo i obucheniye. Pekin, Narodnaya muzyka. $125 \mathrm{~s}$.

About the author:

Li En Hui, postgraduate student at the Faculty of Arts, National Pedagogical Dragomanov University (01054, Kyiv, Ukraine) 